\title{
EMBRYONAL RHABDOMYOSARCOMA OF PROSTATE IN ADULT: A RARE CASE REPORT
}

Dimas Panca Andhika ${ }^{1}$, Sunaryo Hardjowijoto ${ }^{1}$

${ }^{1}$ Department of Urology, Faculty of Medicine, Universitas Airlangga, Surabaya, Indonesia/Dr. Soetomo General Academic Hospital, Surabaya, Indonesia

\section{ABSTRACT}

Rhabdomyosarcoma is the fifth most common type of soft tissue solid tumor in children and the most common in the last two decades. Rhabdomyosarcoma of the urogenital organ is a rare mesenchymal tumor, covering $22 \%$ of all Rhabdomyosarcoma cases. The two most common histologic types are alveolar and embryonal, whereas botryoid and spindle cells are rarely found. We reported cases of embryonal Rhabdomyosarcoma of prostate. In this study, we improved the understanding of Embryonal Rhabdomyosarcoma of prostate on 23 years old male who had history of swelling in the perineal area since 2 months before admission and also had a history of falling from a height in the groin area 5 months before. The patient complains difficulty of urinating and hematuria 1 month after falling. We underwent drainage of the swelling area, found pus $100 \mathrm{cc}$ and took a sample for pathological examination. The result was embryonal rhabdomyosarcoma. Prostate volume was 122cc, PSA 5,32 and PSAD 0,04. The CT scan result was solid mass size $15 \times 8 \times 18 \mathrm{~cm}$ at perineum enhance to pelvic cavity, push the bladder to superior, rectum to posterior, and urethra posterior to the left side. We diagnosed this patient as Embryonal Rhabdomyosarcoma prostate T2bG1NOMO (stage 3) group 3 and intermediate risk group. The patient underwent VAC chemotherapy according to D.9803 (IRS V) protocol, and planned radiotherapy, but it stopped at halfway because of profuse bleeding. Embryonal Rhabdomyosarcoma is an aggressive tumor especially in adults. However, there was limited evidence and guideline to diagnose and management the disease.

Keywords: embryonal; rhabdomyosarcoma; prostate

ABSTRAK

Rabdomiosarkoma adalah tumor solid jaringan lunak terbanyak kelima pada anak dan yang tersering dalam dua dekade terakhir. Rabdomiosarkoma pada organ urogenitalia merupakan tumor mesenkimal yang jarang, hanya 22\% dari seluruh kasus rabdomiosarkoma. Dua jenis histologi yang terbanyak adalah alveolar dan embrional, sedangkan botryoid dan spindle cell jarang ditemukan. Kami melaporkan satu kasus embrional rabdomiosarkoma prostat. meningkatkan pengetahuan tentang rabdomiosarkoma. Studi ini melibatkan laki-laki berumur 23 tahun dengan keluhan benjolan di perineum sejak 2 bulan sebelum masuk rumah sakit dan mempunyai riwayat jatuh dari ketinggian 5 bulan sebelumnya. Pasien mengeluhkan susah buang air kecil dan hematuri sejak 1 bulan setelah terjatuh. Kami melakukan drainase pada lokasi yang bengkak, ditemukan 100 cc pus dan diambil sampel jaringan untuk patologi. Hasil patologinya adalah embrional rabdomiosarkoma. Volume prostat 122cc, PSA 5,32 dan PSAD 0,04. Hasil CT scan didapatkan massa solid berukuran 15x8x18cm pada perineum meluas hingga kavum pelvis, menekan buli ke superior,rektum ke posterior dan uretra posterior ke sisi kiri. Kami mendiagnosis pasien ini embrional rabdomiosarkoma prostat T2bG1NOMO (stage 3) grup 3 dan intermediate risk. Pasien mendapatkan kemoterapi VAC sesuai dengan protokol IRS V dan direncakan radioterapi namun terapi dihentikan karena perdarahan pada massa. Embrional rabdomiosarkoma merupakan tumor yang agresif terutama pada dewasa. Namun, guideline dan kasus sebelumnya sangat terbatas untuk membantu mendiagnosis dan terapi pasien ini.

Kata kunci: embryonal; rhabdomyosarcoma; prostate

Correspondence: Dimas Panca Andhika, Department of Urology, Universitas Airlangga/Dr. Soetomo General Academic Hospital, Surabaya, Indonesia. Email: dimaspanca26@gmail.com

pISSN:2355-8393 • eISSN: 2599-056x • doi: 10.20473/fmi.v57i2.21594

- Fol Med Indones. 2021;57:177-185 • Received 25 Aug 2020 • Accepted 15 Oct 2020

- Open access under CC-BY-NC-SA license • Available at https://e-journal.unair.ac.id/FMI/ 


\section{INTRODUCTION}

Sarcoma is one of the malignancies despite carcinoma. Incidence rate of sarcoma was fewer than carcinoma. Sarcoma usually occured and developed at bone or soft tissue (Burningham 2012). Osteosarcoma and ewing sarcoma was some kinds of sarcoma that grow at bone, while other sarcomas could be developed at muscle, fat tissue, blood vessel, or elsewhere at sotf tissue around the body (Raney 2001). The example of soft tissue sarcomas were fibrosarcoma, liposarcoma, angiosarcoma, leiomysarcoma, rhabdomyosarcoma, synovial sarcoma, malignant schwanoma, and many others (Monfardini 1987).

Sarcoma counted approximately $1 \%$ and $21 \%$ of all solid tumor in adults and in children respectively (Burningham 2012). Soft tissue sarcoma was $5^{\text {th }}$ highest solid tumor in children. Rhabdomyosarcoma (RMS) is one of soft tissue sarcoma that often occurred in the last 20 years (Rosenberg 2010). In the United States, the incidence rate of RMS was 3\% and around 350 new cases were detected every year (Jernal 2010). Monfardini (1987) stated that RMS occurs at average 6 years old child. RMS sex ratio is around 1,1 and 1 for man and woman respectively. Some genetics factor that can cause RMS, such as Von Recklinghausen's Disease, basal cell naevomatosis, lung adenomatocys, nervus cebaseous of Jadassohn and familial tumor history, such as breast cancer, soft tissue cancer, brain cancer, adrenocortical cancer or osteosarcoma (Burningham 2012).

RMS is a mesenchymal sarcoma that occured from striated muscle. Two hystological type which most often found were alveolar and embryonal RMS (Bejar 2014). The study of Monfardini (1987) had found that embryonal type has $57 \%$ incidence rate, $18 \%$ of alveolar type, $7 \%$ of botryoid, $2 \%$ of pleomorphic adult type, and undifferentiated has incidence rate 16\%. Embryonal type has better outcome compared to alveolar type (Rafsanjani 2007). RMS has good prognosis if it occured at eye, bladder, vagina or paratesticular, but if it occured at vesicoprostatic, extremity and body, the prognosis become intermediet. RMS that occured at nasofaring and middle part of ear canal have poor prognosis. Embryonal Rhabdomyosarcoma (ERMS) growth occurred mostly at head-neck and genitourinary area (Bejar 2014).

Genitourinary RMS count around 22\% of all RMS (Bejar 2014). The symptoms were urinary tracr obstruction, urine retention, frequency, and incontinence. Gross hematuria or microscopic hematuria can be found if the tumor has been infiltrated mucosal surface (Ferrer 2006). At phisycal examination, we can find the tumor if its origin was bladder or prostate. We can palpate the bladder or prostate from direct recal examination. The tumor usually has solid form and rarely has sistemic symptom (Ferrer 2016). The diagnostic tools including urinalysis, urine culture, urine cytologi and imaging. CT scan or MRI are two imaging that can determine and explain the detail of tumor. Cystoscopy an be done if needed to get a visual inspection along the genitourinary tract and biopsy sample for diagnostic. If the lesion can not be foung along rhe tract, it is sugessted to do ultrasonography (USG) or CT scan guided percutaneous needle biopsy. If the diagnostic tools above cannot determine the tumor, so that surgical exporation and excisional biopsy can be done (Defoor 2002). The metastase was examined using thorax xray, CT scan, bone marrow aspiratioe, bone scan, or suspicious lymph node biopsy (Monfardini 1987).

The principal treatment of RMS are local control, protecting affected organs and preventing metstase (Monfardini 1987). The treatment of RMS follows protocol from Intergroup Rhabdomyosarcoma Study (IRS). It is recommended to treat muldidiciplinary according to hitological subtype and location of primary tumor (Kalmadi 2008). Survival rate was different based on each clinical group (I-IV) (Raney 2001).

Surgical treatment is one of the most effective methods to eradicate local tumor without significant residual mass $(<30-40 \%$ cases). On other cases, they firstly underwent biopsy than surgical treatment underwent after shrinkage of tumor following chemotherapy or radiotherapy. The objetive of chemotherapy were local control after excision with or without radiotherapy, treatment of metastase, eradication of micrometastase, and neoadjuvant therapy to shrinkahge the tumor after biopsy. 1,2,3 We reported an genitourinary RMS at prostate.

\section{CASE PRESENTATION}

The subject was male aged 23 years old worked as a private employee. The patient came to emergency ward at Dr. Soetomo General Academic Hospital in April 19, 2017. The patient had a chief complaint fever for two weeks before admission. The patient also complained swelling at perinal area in two months before. He complained the swelling was getting bigger and pain. The patient also complained difficulty to defecate. He also had a history of perineal trauma because of an accident in the previous five month before admission. A month after the accident, the patient felt voiding difficulties than installed urine catheter at Malaysia. 
The initial physical examination, we found general condition were fair, stable vital sign and karnofsky's score was $70 \%$ (Patient could not do daily activity normally). The head and neck examination, found anemis and pale acral. The genitalia was seen sweelling at perineal area with warm palpation sugessting an abcess. (Figure 1).

At April 25, 2017 patient underwent incison and abcess drainage, debridement, necrotomy, and open cystostomy. They collected pus estimatedly 100cc and underwent culture pus swab. After the surgery, found granulating wound and yellow necrotic. At direct rectal examination, the mass seems at the extralumen and fragile.

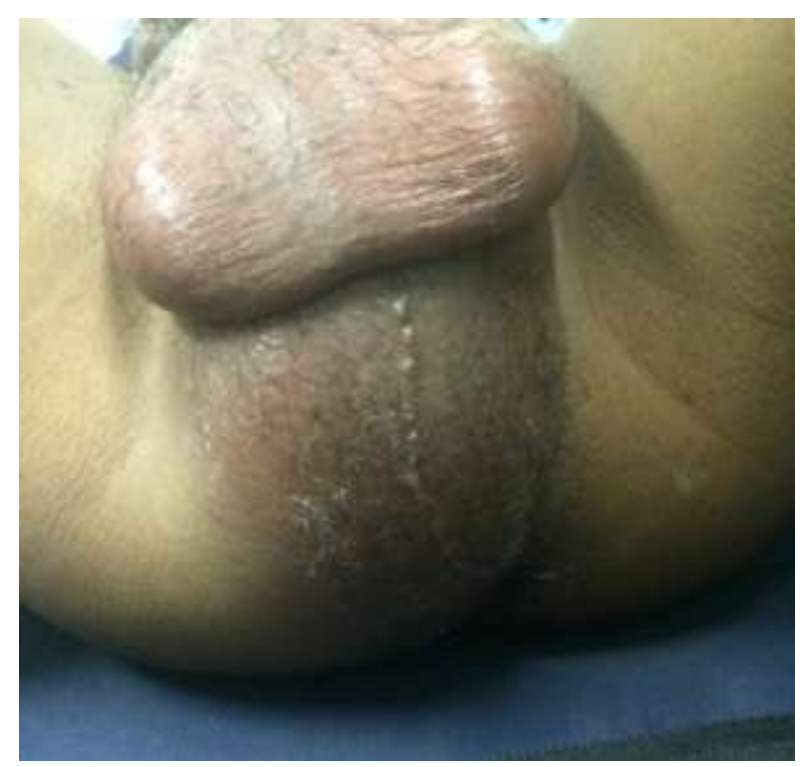

Figure 1. Swelling at perieal region

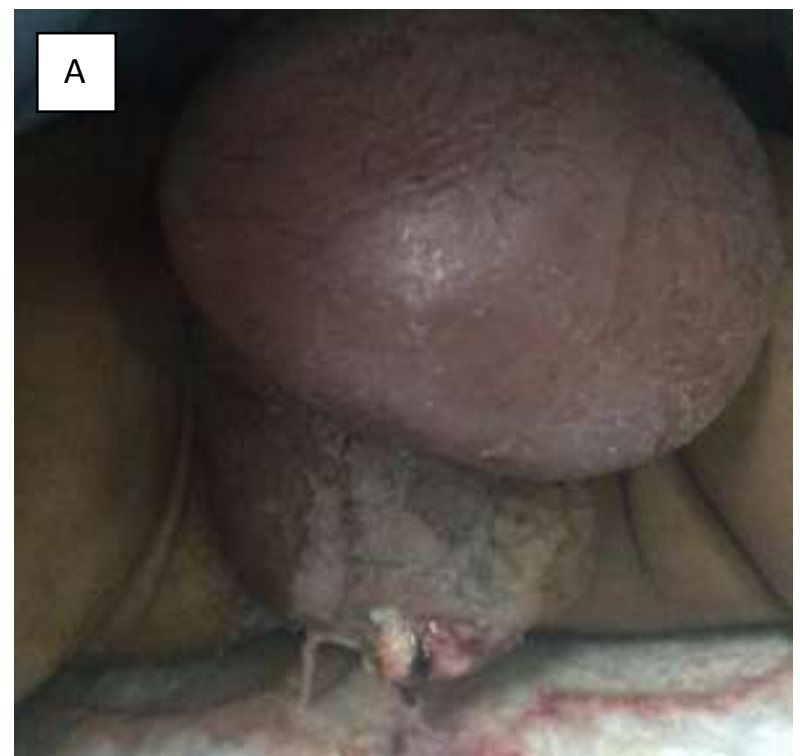

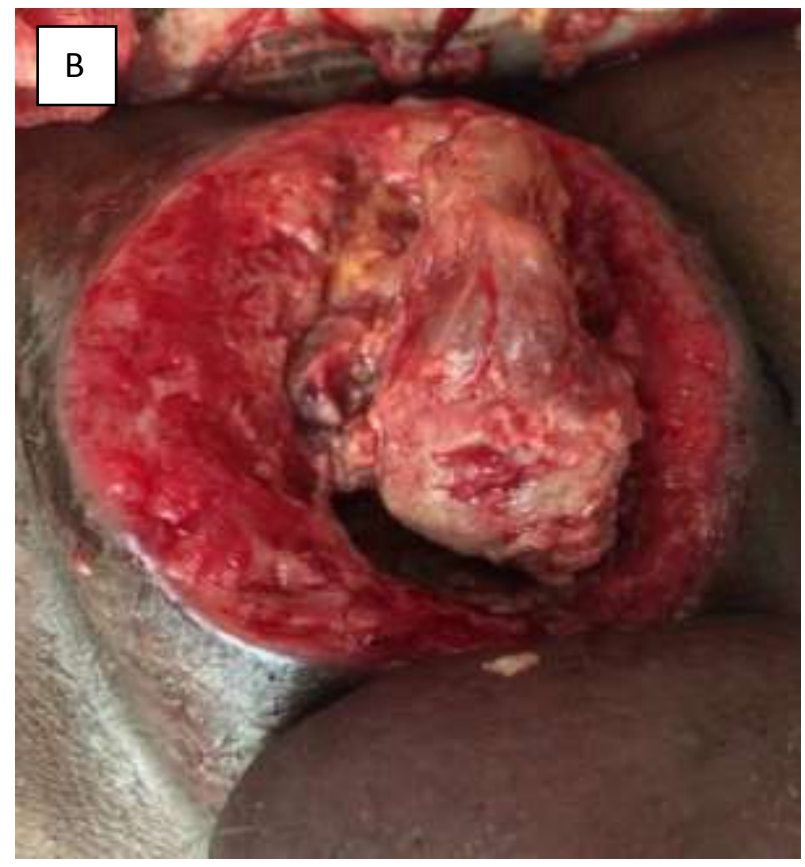

Figure 2. The abcess after incision $[\mathrm{A}]$, the granulating wound and yellow necrotic [B]

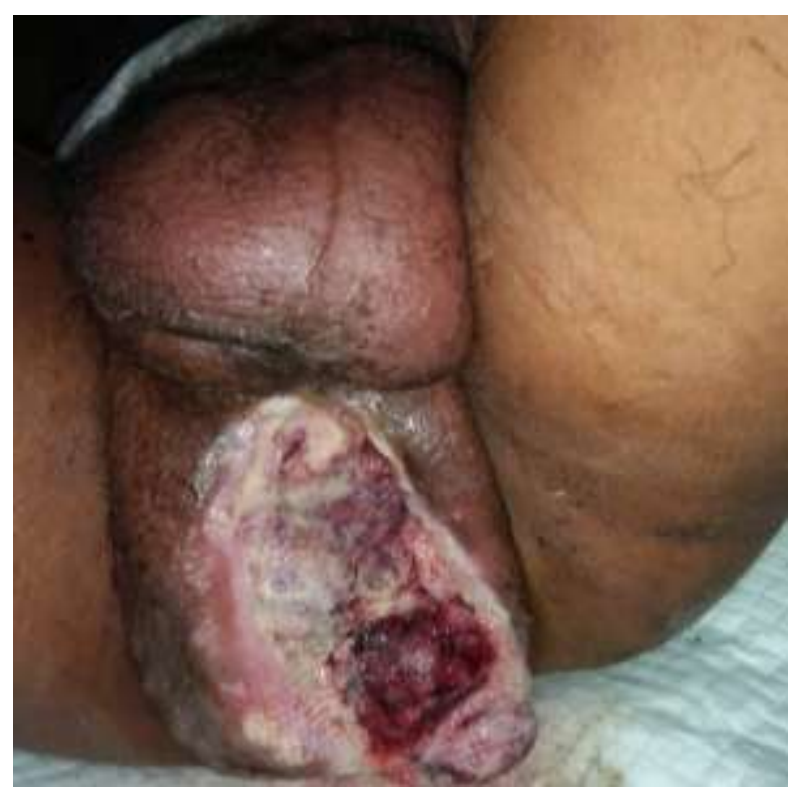

Figure 3. The granulating wound and yellow necrotic

The initial laboratory finding (18/4/2017), found leucocyte $9,8 \times 10^{3} / \mu \mathrm{L}$, hemoglobin $12,4 \mathrm{~g} / \mathrm{dL}$, and platelets $70 \times 10^{3} / \mu \mathrm{L}$. Renal function found blood urea nitrogen (BUN) $18 \mathrm{mg} / \mathrm{dL}$ and creatinine serum 0,85 $\mathrm{mg} / \mathrm{dL}$. Urinalysis result $\mathrm{pH} 5,5$; erytrocyte 5-10 per field of view dan leucocyte 25-50 field of view. The result of urine, blood and pus culture was the same (Extended-spectrum beta-lactam) ESBL positive. 
The initial radiology finding were ultrasonography (USG) and transrectal ultrasonography (TRUS) at March 16, 2017. Then, abdominal xray, thorax xray and abdominal USG at April 19, 2017. We found prostate volume $80 \mathrm{cc}$ and no mass at the bladder from abdominal USG (Figure 4). The patient underwent TRUS (Figure 5) at March 16 ${ }^{\text {th }}, 2017$ and the result were prostate volume $122 \mathrm{cc}$ with Prostate specific antigen density (PSAD) 0,04; Prostate spesific antigen (PSA) 5,32; no hipoechoic lesion or calcficaion. Abdominal xray found ground glass appearance at pelvic cavity and no radioopaque shadow along urinary tract (Figure 6). Thorax xray did not find any anomali from cardio and pulmo or sign of metastase (Figure 7).

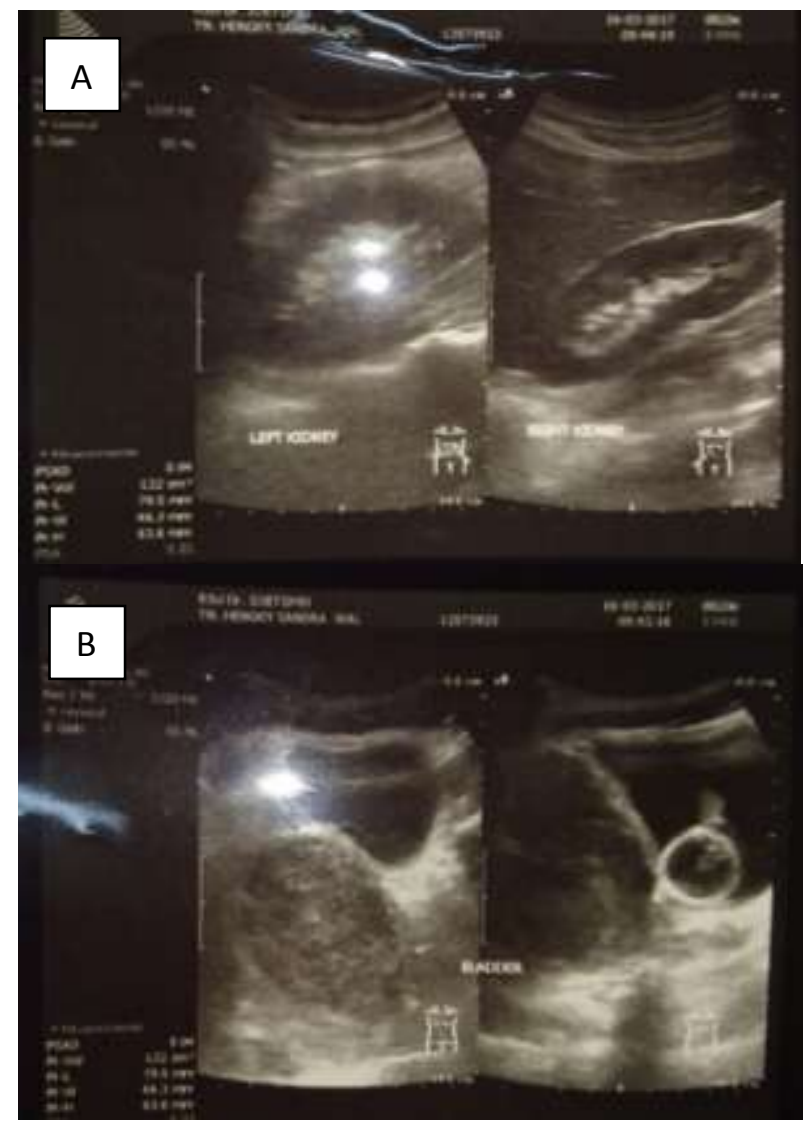

Figure 4. Normal right and left kidney (A); prostate volume $80 \mathrm{cc}$ and no mass at bladder (B)

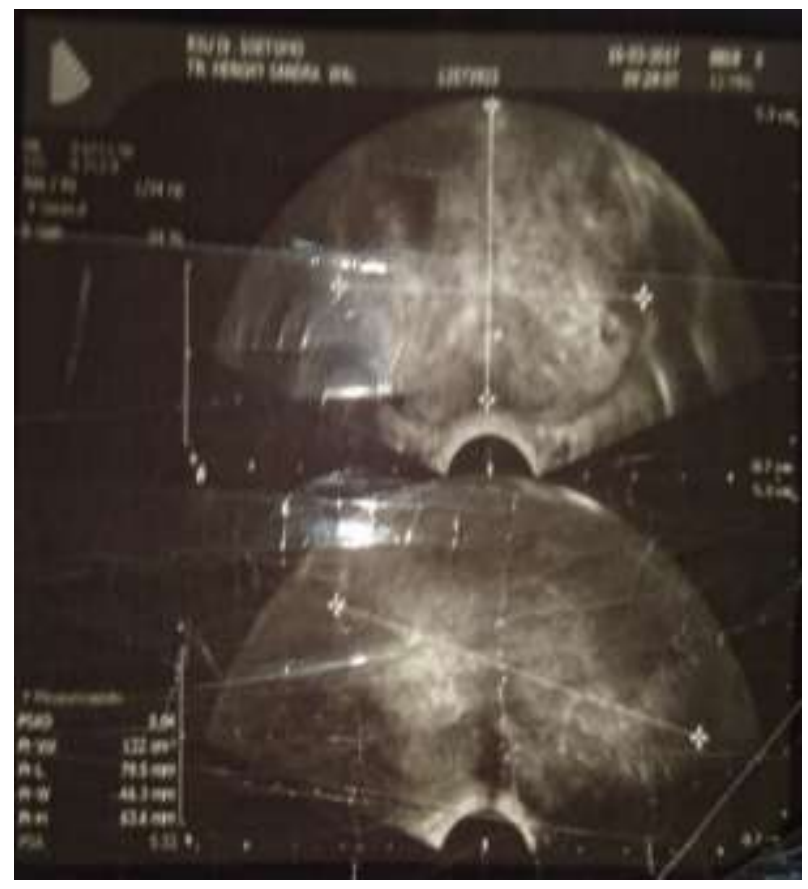

Figure 5. TRUS found prostate volume $122 \mathrm{cc}$ with PSA 5,32; PSAD 0,04, no hipoechoic lesion or calcification

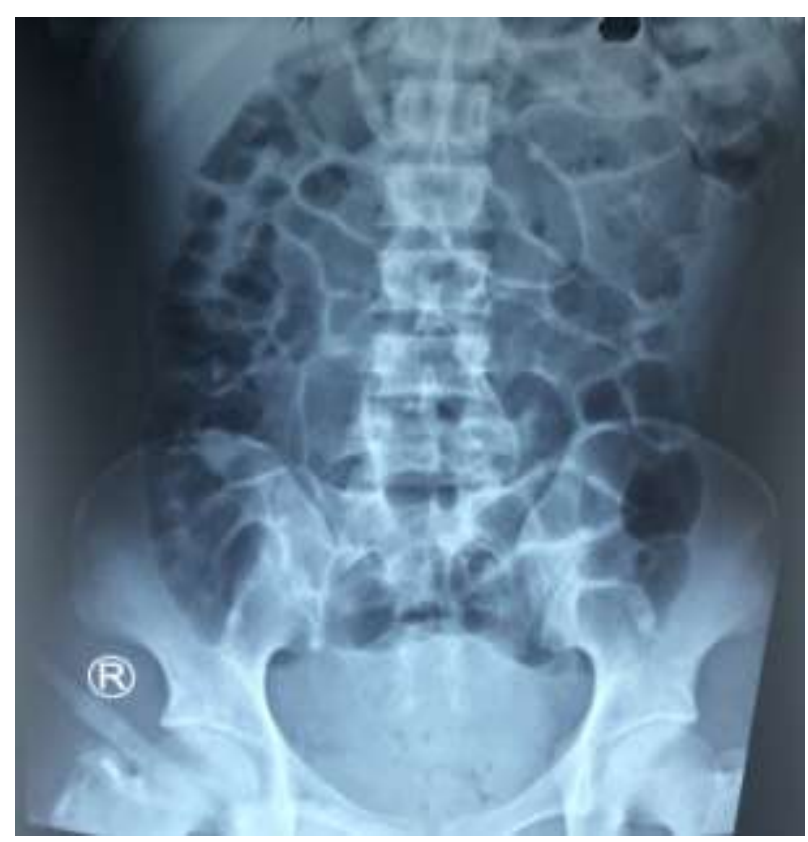

Figure 6. Abdominal xray found ground glass appearance at pelvic cavity 


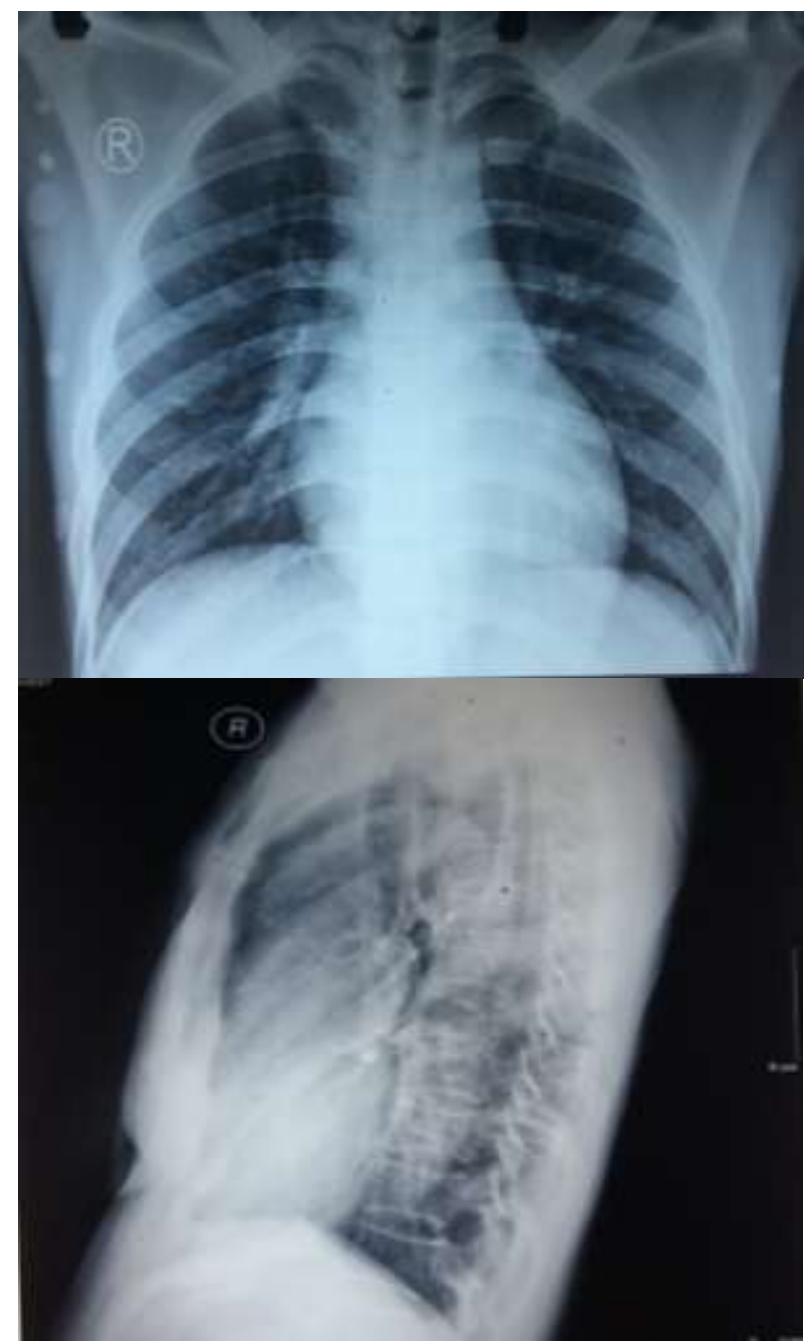

Figure 7. Thorax xray cor and pulmo wihtin normal limit and no sign of metastase

At April 19, 2017 patient underwent evaluation USG (Figure 8) and at April 20th, 2017 patient underwent abdominal CT scan with contras. From the evaluation USG (Figure 9) we found heterogene solid mixed cystic lesion echogenic with no clear border, ireguler side with size $15,5 \times 8,7 \times 5,6 \mathrm{~cm}$ at perineal region and adhere to inferolateral bladder wall with clear border with testis, and other organ within normal limit. From the abdominal CT scand we found slight semi solid enhancement lesion size $15 \times 8 \times 18 \mathrm{~cm}$ at perineum expand to pelvic cavity, pressing bladder to superior, rectum to posterior, posterior urethra to the left side and air density at the surrounding probably caused by perineum abcess that extend to pelvic cavity (Figure $10)$.

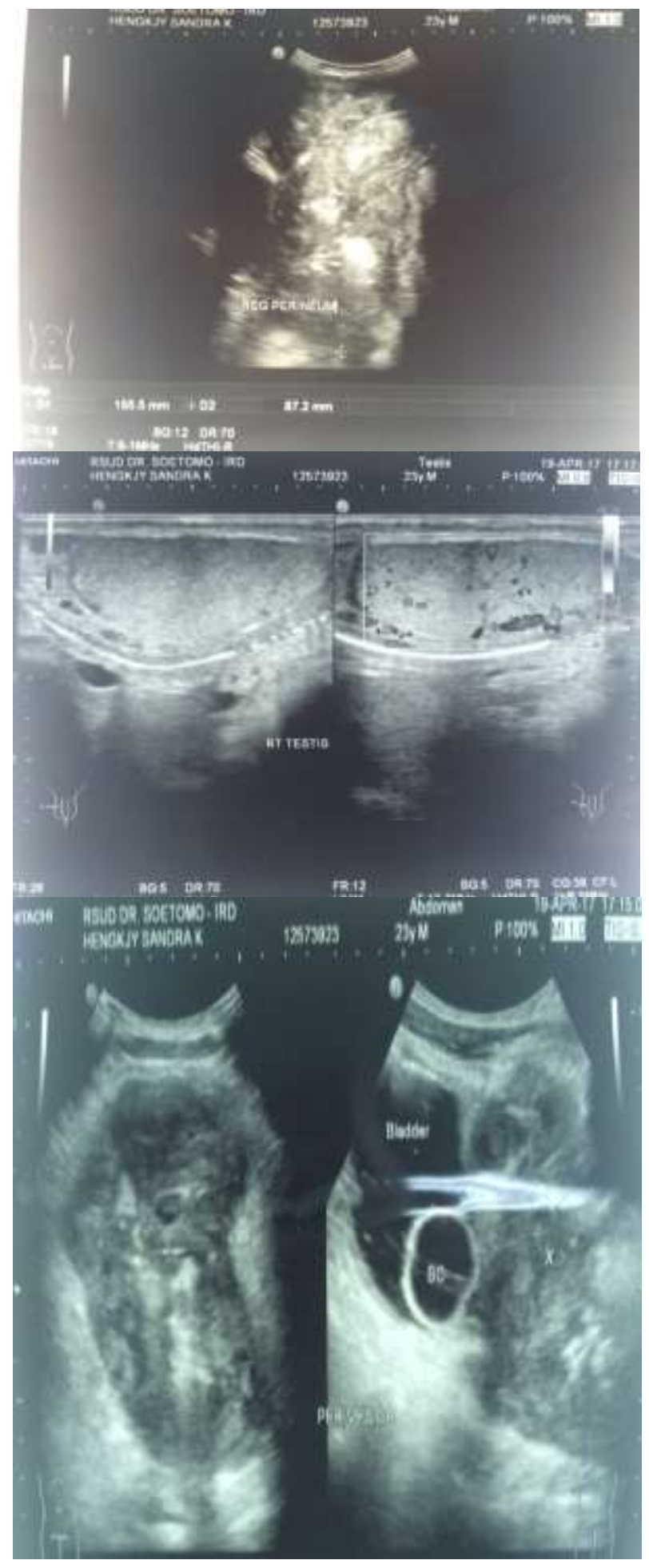

Figure 8. USG seen solid mixed cystic heterogen echogenic lesion with unclear border, iregular edge size $15,5 \times 8,7 \times 5,6 \mathrm{~cm}$ at perineal regio, adhere to inferolateral side of bladder wall 


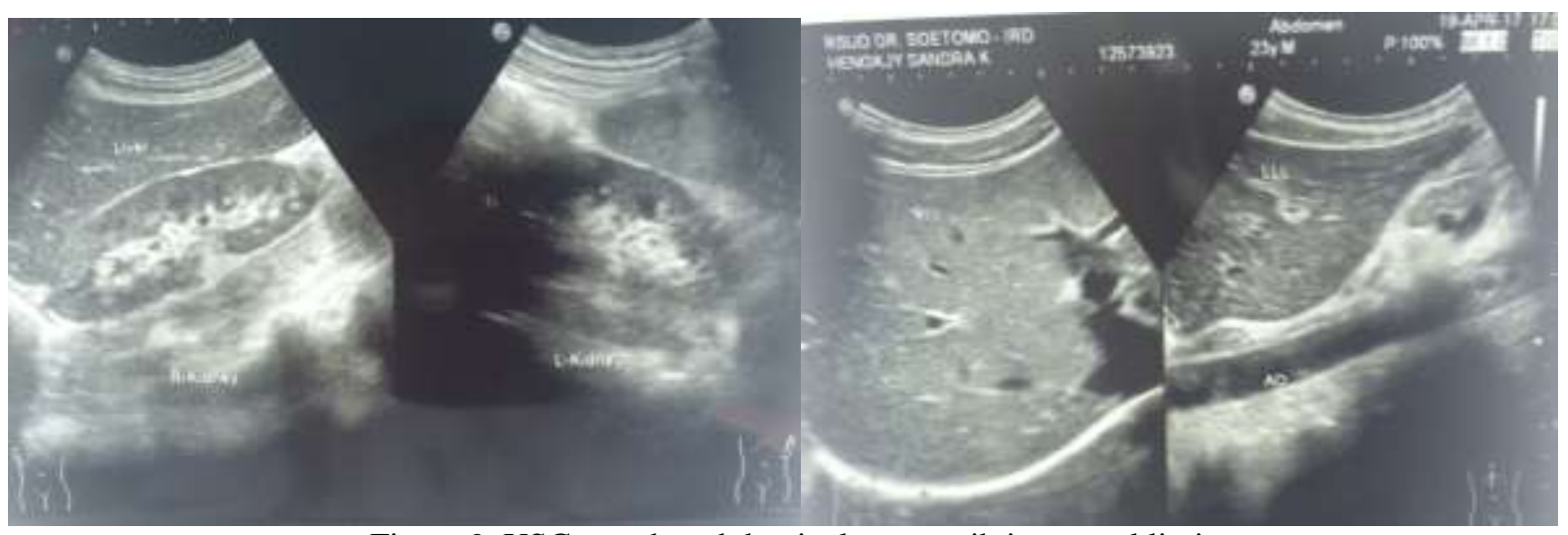

Figure 9. USG: another abdominal organ wihtin normal limit

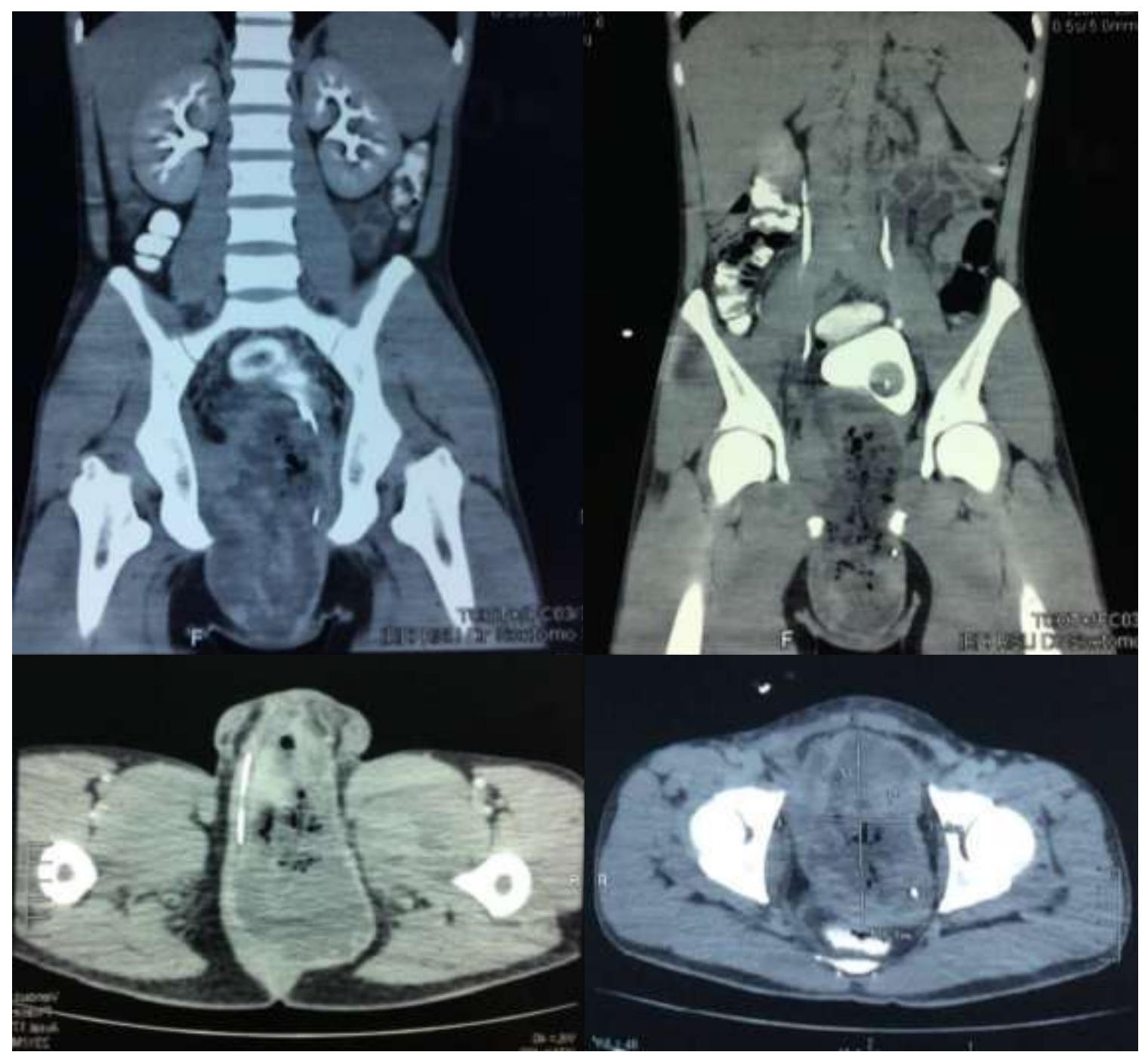

Figure 10. CT scan seen semi solid heterogenous enhancment size $15 \times 8 \times 18 \mathrm{ccm}$ at perineum that extend to pelvic cavity pressing bladder to superior, rectum to posterior, posterior urethra to the left and air density at the surrounding probably caused by perineum abcess that extend to pelvic cavity 


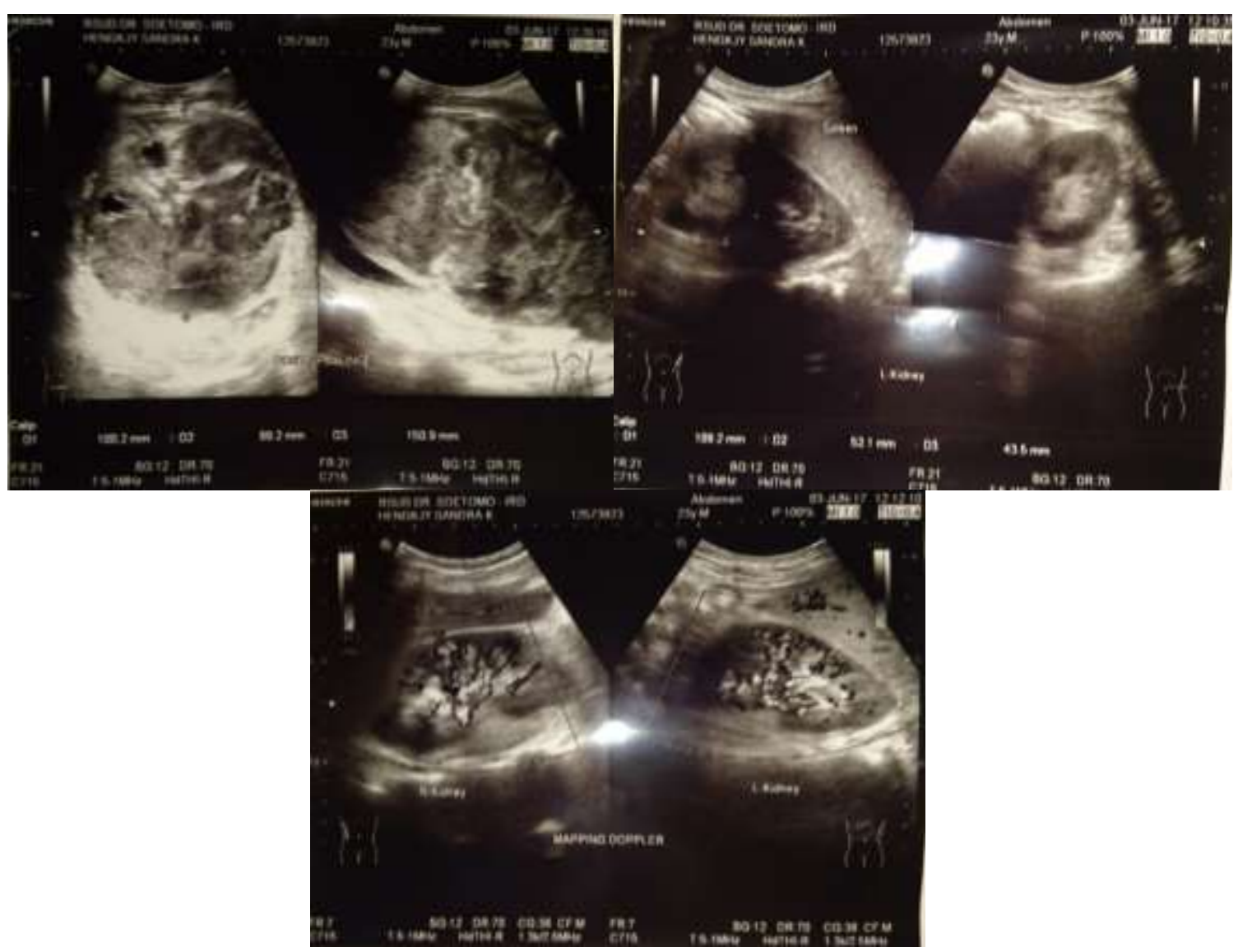

Figure 11. Heterogen mixed solid lesion, Unclear border, irregular edge, size 10x10x15cm, with full mass at the bladder

At Juny 1st, 2017 the patient underwent evaluation USG. We found hetetogen mixed solid lesion, irregular edge, size $10 \times 10 \times 15 \mathrm{~cm}$ with full mass at bladder (Figure 11).

The basic principle of RMS treatment were sistemic (chemotherapy) and local control (surgical and radiotherapy). The intencity and time to start the treatment must be planned accoding to the patient risk stratification and treatment side effect. We diagnosed this patient Embryonal Rhabdomyosarcoma of Prostate T2bG1N0M0 infiltrating to perineum and bladder. This patient was included to intermediate risk group because of Embryonal type RMS, and included to group 3 because of incomplete resection or biopsy with large residual mass at 23 years old when he was diagnosed. We planned VAC chemotherapy amd radiotherapy to this patient.

\section{DISCUSSION}

Rhabdomyosarcoma is the third most often extracranial solid tumor in children after neuroblastoma and wilms tumor and approximately counts $4 \%$ of all carcinoma in Pediatric. There were around $15-20 \%$ of RMS found at genitourinary system especially bladder, psostate and paratesticular. There were 3 type of RMS, such as embryonal (80\%), alveolar (15-20\%) and pleomorphyc. Botryoid and spindle cell type were other variants of embryonal RMS. Botyroid RMS predilection was on hollw organ, such as bladder or vagina. The spindle cell RMS usually could be found in paratesticular and have a good prognosis. Alveolar RMS (ARMS) could be found at young age and related to poor prognosis. Either alveolar and embryonal RMS could have rhabdoid tumor like or anaplasia appearance (Swinson, 2011).

Fifty one RMS cases have been indentified by Alanee and Sukhla in bladder cancer cases. This tumor was mostly found in 1-4 years old children and male suffered more than female (Alanee 2009). Patient mostly underwent external beam radiotherapy approximately $63 \%$ as primary treatment or adjuvant. Bladder embryonal RMS survival rate counts $50-80 \%$ in $<4$ years old patients (Ferrari, 2002). 
RMS clinical presentation was different according to location, patient age, and metastase status. The symptoms were usually felt because of tumor suppresion or lymph node spreading (Swinson 2011). RMS can be developed in children who has type 1 neurofibromatosis, costello syndroeme, BeckwithWiedemann Syndrome and Li-Fraumeni Syndrome (Lopez et al 1998). The symptoms could occur, such as urinary tract obstruction, urine retention, urgency, frequency, and incontinence. Gross hematuria or microsopic hematuria could be found if the tumor infiltrate to mucous (Ferrer 2006).

The differential diagnose of RMS including spindle cell lesion, inflammatory myofibroblastic tumor (IMT), leiomyosarcoma, neurofibroma, and sarcomatoid carcinoma. This tumor could be differentiated by morfology and clinical connection. Immunohistochemistry at tumor specimen that supported differentiation of striated muscle could help to diagnose RMS (Lott 2007).

The principle of RMS treatment was multimodality treatment including systemic (chemotherapy) and local control (surgery with or without radiothrerapy). Intencity and time to treatment must be planned according to risk stratification and side effect of treatment. It was recommended not to do agressive surgery in the bladder embryonal RMS patient, despite doing chemotherapy than evaluation using imaging. Biopsy could be done to preserve the bladder (Raney 2001).

We diagnosed our patient as embryonal rhabdomyosarcoma of prostate T2bG1N0M0 infiltrating to perineum and bladder. This patient belonged to intermediate risk group because of embryonal RMS histology, and belonged to group 3 because of incomplete resection of tumor or biopsy with large residual mass and age when diagnosed 23 years old (Ferrer 2016). This group recommended to be treated with VAC or alternative VAC chemotherapy using vincristine, cyclosphamide and topotectan simultaneosly with radiotherapy (Raney 2001, Monfardini 1987).

VAC regiment (after year 2000) composed of $1.5 \mathrm{mg} / \mathrm{m}^{2}$ vincristine intrvenous at day-1, 8 and $15 ; 2.2 \mathrm{~g} / \mathrm{m}^{2}$ Cyclosphamide intravenous at day- 1 , and $1.5 \mathrm{mg} / \mathrm{m}^{2} \mathrm{D}$ actinomycin intravenous at day-1. The treatment repeated according to Children's Oncology Group (COG) Study (D9803) (Arndt 2009).

Kojima et al (2012) reported a retrospective study to evaluate effect of VAC children and adult RMS patient. They stated that age was negative prognostic factor to progression free survival (PFS) rate at RMS cases which still localised and did not relate with survival of metastase cases.

A study by Rodeberg et al (2011) stated some factors that related to treatment failure in intermediate risk patient were tumor volume, body weight, and histology. If tumor volume and body weight were ignored, so longest tumor diameter, age and location of primary tumor were some factors that retated to risk of failure treatment.

The local control using radiotherapy at primary site of tumor was recommended in RMS patient with metastase, because it would increase overall survival (OS). Time to start local treatment using radiotherapy or surgery must be adjusted according to patient condition. Radiotherapy total dose was between 30-56,3 Gy with median dose 45 Gy (Arndt 2009).

Target size of radiotherapy was $2 \mathrm{~cm}$ maximum before surgery and chemotherapy. Radiotherapy usually started at $9^{\text {th }}$ week. This treatment must be discontinue if neutrophil counted $\leq 750$ or platelets $<75000$. The usage of D-actinomycin and VP-16 should be stopped, while the patient underwent radiotherapy (Raney 2001).

Our patient had been planned to receive VAC chemotherapy and radiotherap.y. The chemotherapy had been done halfway, but the radiotherapy had not been done yet. After some chemotherapy, the mass did not look smaller. The treatment was delayed because of unfit condition of the patient caused by profuse bleeding at the tumor. Unfortunately, the patient had passed away before the treatment completed.

\section{CONCLUSION}

Embryonal Rhabdomyosarcoma is an aggressive tumor especially in adults. The type of treatment, intencity and time of treatment should be planned according to patient risk stratification and side effect of treatment. The treatment should follow Intergroup Rhabdomyosrcoma Study (IRS) procotol and suggested to do multidiciplinary.

\section{ACKNOWLEDGMENT}

Thanks to Soenaryo Hardjowijoto for the guidance, all Urology Department staff, all Urology residents of Universitas Airlangga, my family and Dr. Soetomo General Academic Hospital for the valuable support. 


\section{REFERENCES}

Alanee S, Shukla AR (2009). Bladder malignancies in children aged <18 years: Result from the surveillance epidemiology and end result database. BJU International 106, 557-560.

Arndt CA, Stoner JA, Hawkins DS, et al (2009). Vincristine, actinomycin, and cyclophosphamide compared with vincristine, actinomycin, and cyclophosphamide alternating with vincristine, topotecan, and cyclophosphamide for intermediaterisk rhabdomyosarcoma: Children's oncology group study D9803. J Clin Oncol 27, 5182-5188.

Bejar DE, Huh WW (2014). Rhabcomyosarcoma in adolescent and young adult patients: Current perspective. Adolescent Health, Medicine and Therapeutics 5, 115-125.

Burningham Z, Hashibe M, Spector L, et al (2012). The epidemiology of sarcoma. Clinical Sarcoma Research 2, 1-16.

Defoor W, Minevich E, Sheldom C (2002). Unusual bladder mass in children. Urology 60, 911.

Ferrari A, Bisogno G, Casanova M, et al (2002). Paratesticular rhabdomyosarcoma: report from the Italian and German cooperative group. J Clin Oncol 20, 449-55.

Ferrer FA, Isakoff M, Koyle MA (2006). Bladder/prostate rhabdomyosarcoma: Past, present and future. J Urol 176, 1283-91.

Ferrer FA (2016). Pediatric urology oncology: Bladder and testis in Campbell Walsh urology (11th Edition), Netherlands, Elsevier, p P3582-3598.

Jernal A, Siegel R, Xu J, et al (2010). Cancer statistics 2010. CA Cancer J clin 60, 277-300.

Kalmadi S, Raghavan D (2008). Principles of chemotherapy for genitourinary cancer. In: Nargund
VH, Raghavan D, Sandler HM. Urological oncology, London, Springer-Verlag, p 194-212.

Kojima Y, Hashimoto K, Ando M, et al (2012). Clinical outcomes of adult and childhood rhabdomyosarcoma treated with vincristine, d-actinomycin, and cyclophosphamide chemotherapy. J Cancer Res Clin Oncol 138, 1249-1257.

Lopez-Beltran A, Montironi R, Vidal-Jimenez A, et al (2007). Pathology of tumors of the urinary bladder. In: Mikuz G. Clinical pathology of urologic tumors, United Kingdom, Informa Healthcare, p 57-89.

Lott SL, Lopez-Beltran A, Montironi R, et al (2007). Soft tissue tumors of the urinary bladder Part II: Malignant neoplasm. Human Pathology 38, 963-977.

Monfardini S, Brunner K, Crowther D, et al (1987). Manual of adult and pediatric medical oncology, Germany, Springer, p 279-285

Rafsanjani KA, Vossough P, Bashardoust A, et al (2007). Survival rate of children with rhabdomyosarcoma and prognostic factor. World $\mathbf{J}$ Pediatr 3, 36-40.

Raney RB, Maurer MH, Anderson JR, et al (2001). The intergroup rhabdomyosarcoma study group: Major lessons from the IRS-I through IRS-IV studies as background for the current IRS-V treatment protocols. Sarcoma 5, 9-15.

Rodeberg DA, Stoner JA, Garcia-Henriquez N, et al (2011). Tumor volume and patient weight as predictors of outcome in children with intermediate risk rhabdomyosarcoma (RMS): A report from the children's oncology group. Cancer 117, 2541-2550.

Rosenberg AE (2010). Bones, joints, and soft-tissue tumors. In: Kumar V, Abbas AK, Fausto N, et al. Robbins and Cotran Pathologic Basis of Disease $8^{\text {th }}$ ed, New York, Saunders Company, p 1253-1254.

Swinson S, McHugh K (2011). Urogenital tumours in childhood. Cancer Imaging 11, S48-S64. 